\title{
A statistical approach to disentangle environmental forcings in a lacustrine record: the Lago Chungará case (Chilean Altiplano)
}

\author{
S. Giralt ${ }^{\mathrm{a}, *}$, A. Moreno ${ }^{\mathrm{b}}$, R. Bao ${ }^{\mathrm{c}}$, A. Sáez ${ }^{\mathrm{d}}$, R. Prego ${ }^{\mathrm{e}}$, B.L. Valero ${ }^{\mathrm{f}}$, J.J. Pueyo ${ }^{\mathrm{g}}$, P. \\ González-Sampériz ${ }^{\mathrm{f}}$, C. Taberner ${ }^{\mathrm{h}}$ \\ a Institute of Earth Sciences "Jaume Almera" (CSIC), Lluís Solé i Sabarís s/n, E- \\ 08028 Barcelona (Spain) \\ ${ }^{\mathrm{b}}$ Limnological Research Center, Department of Geology and Geophysics, University \\ of Minnesota, 220 Pillsbury Hall, 310 Pillsbury Drive S.E., Minneapolis, MN 55455- \\ 0219 \\ c Facultade de Ciencias, Universidade A Coruña, Campus da Zapateira s/n, E-15071 \\ A Coruña (Spain) \\ d Department of Stratigraphy, Paleontology and Marine Geosciences, Faculty of \\ Geology, University of Barcelona, Martí i Franquès s/n, E-08028 Barcelona (Spain) \\ e Marine Biochemistry Research Group, Marine Research Institute (CSIC), Eduardo \\ Cabello 6, E-36208 Vigo (Spain) \\ ${ }_{\mathrm{f}}^{\mathrm{f}}$ Pyrenean Institute of Ecology (CSIC), Apdo 202, E-50080 Zaragoza (Spain) \\ g Department of Geochemistry, Faculty of Geology, University of Barcelona, Martí i \\ Franquès s/n, E-08028 Barcelona (Spain) \\ h Shell International Exploration and Production B.V., Carbonate Team, Kesslerpark \\ 1, 2288 GS Rijswijk (The Netherlands)
}

\begin{abstract}
A high resolution multiproxy study (magnetic susceptibility, x-ray diffraction, XRF scanner, gray-colour values, Total Organic Carbon, Total Inorganic Carbon, Total Carbon and Total Biogenic Silica) of the sedimentary infill of Lago Chungará (northern Chilean Altiplano) was undertaken to unravel the environmental forcings controlling its evolution using a number of different multivariate statistical techniques. Redundancy Analyses enabled us to identify the main provenance of the studied proxies whereas stratigraphically-unconstrained cluster analyses allowed us to distinguish the "outsiders" as result of anomalous XRF scanner acquisitions. Principal Component Analysis (PCA) was employed to identify and isolate the main underlying environmental gradients that characterize the sedimentary infill of Lago Chungará. The first eigenvector of the PCA could be interpreted as an indicator of changes in the input of volcaniclastic material, whereas the second one would indicate changes in water availability. The chronological model of this sedimentary sequence was constructed using 17 AMS ${ }^{14} \mathrm{C}$ and $1{ }^{238} \mathrm{U} /{ }^{230} \mathrm{Th}$ dates in order to characterize the volcaniclastic input and the changes in water availability in the last 12,300 cal years BP.

Comparison of the reconstructed volcaniclastic input of Lago Chungará with the dust particle record from the Nevado Sajama ice core suggested that the Parinacota volcano eruptions were the main source of dust during the mid and late Holocene rather than the dry out lakes as has previously been pointed out. The comparison of the water availability reconstruction of Lago Chungará with three of the most detailed paleoenvironmental records of the region (Paco Cocha, Lake Titicaca and Salar Uyuni) showed an heterogeneous (and sometimes contradictory) temporal and spatial pattern distribution of moisture. Although the four reconstructions showed a good correlation, each lacustrine ecosystem responded differently to the moisture
\end{abstract}


oscillations that affected this region. The variations in the paleoenvironmental records could be attributed to the dating uncertainities, lake size, lake morphology, catchment size and lacustrine ecosystem responses to the abrupt arid events.

Key words: Chilean Altiplano, Lago Chungará, Holocene, Statistical analyses, Principal Component Analysis, Redundancy Analysis, stratigraphically-unconstrained cluster analysis, water availability reconstruction.

\section{Introduction}

Lakes are one of the best and most precise continental sensors of environmental change (Fritz 1996; Battarbee 2000). These changes provoke variations in the physico-chemical conditions of the lake water body, which in turn, induce changes in their biota assemblages, the precipitation of mineralogical phases, and/or variations in the stable isotope values, among others. Such changes are usually well-preserved in the sediments. Hence, lakes have been widely used to reconstruct past environmental changes. This is especially true when reconstructing past climatic and land use changes in a given region (Pla and Catalan 2005).

One of the most important limitations in the use of lacustrine records as past environmental archives is the difficulty of differentiating the main forcings (climate, tectonism, volcanism, anthropogenic influence) that trigger these environmental lacustrine changes. Many lakes are located in highly tectonic and/or volcanically active areas (e.g. lakes of the African rift and of the Andean Cordillera), or close to large urban areas where there is an intensive use of the catchment area (e.g. Lake Constance), making it difficult to distinguish the climatic signal from other processes. Even lakes located in remote areas have demonstrated that they can be markedly affected by anthropogenic activities (Camarero et al. 1995; Carrera et al. 2002). Hence, a detailed paleoenvironmental reconstruction must clearly identify and isolate the different signals.

One way to identify these signals in recent sediments is to use a statistical approach. Ordination analyses such as Component Analyses have proved to be effective in highlighting (1) the underlying environmental processes that trigger the recent marine facies distribution (Hennebert and Lees 1991), (2) the periodic change in the marine water current regime (Vlag et al. 2004), (3) the mineralogical composition of the hypersaline lacustrine sediments (Rodó et al. 2002; Giralt and Julià 2003) and (4) the variations in the composition of phytoplankton groups (Vink et al. 2003). Ordination analyses allow us to arrange samples and variables along axes which are a linear combination of the original variables and represent independent theoretical environmental gradients. Consecutive axes explain decreasing percentages of the total variance. Thus, the first axis (x-axis) would cause the largest variation, the second axis (y-axis) would represent the second largest source of variation, and so forth. The ordination analyses are diagrams where the samples are arranged in a space where those that are close together represent similar underlying environmental conditions whereas those spaced apart indicate dissimilar conditions (ter Braak 1987).

An understanding of tropical climate circulation and its temporal evolution since the Last Deglaciation is essential in order to characterize the moisture transport mechanisms towards the extra-tropical areas. One way to achieve this is by studying high-resolution multi-proxy lacustrine sequences located in tropical South America. At present, however, our understanding of the tropical climate variability during the 
Holocene is limited to a small number of high-resolution sedimentary sequences (Marchant and Hooghiemstra 2004).

Here, we present a methodology to qualitatively characterize and isolate the different forcings that have controlled the sedimentary infill of Lago Chungará (Chilean Altiplano) for the last 12,300 cal yrs. BP. To this end, it is hoped that a deeper insight into the tropical paleoclimatic variability in the late Quaternary will be obtained.

\section{Geographical and geological setting}

Lago Chungará is located at the northeastern edge of the Lauca Basin, in the Chilean Altiplano, at 4,520 m above sea level (Figure 1A). This lake lies in a highly active tectonic and volcanic context (Wörner et al. 1988; Clavero et al. 2002; Hora et al. 2007). The lake resulted from a debris avalanche during the partial collapse of the Parinacota volcano, which dammed the Lauca River. The age of this collapse is not well-constrained, and it ranges from 18,000 years (Wörner et al. 1988; Hora et al. 2007) to 8,000 years BP (Clavero et al. 2002).

The lake has an irregular shape with a maximum water depth of about $40 \mathrm{~m}$, a water surface area of about $21 \mathrm{~km}^{2}$ (Figure 1B), and an approximate water volume of 385 $\mathrm{Hm}^{3}$ (for further details see Valero-Garcés et al. (2003)). At present, the main water input is the Chungará River (300 - $460 \mathrm{ls}^{-1}$ ) although secondary rivers and streams are present around the lake. The main water outputs are evaporation $\left(1,230 \mathrm{mmy}^{-1}\right)$ and groundwater outflow (estimated at about $6.10^{6} \mathrm{~m}^{3} \mathrm{y}^{-1}$ ) (see Herrera et al. (2006) for further details). The lake has been described as cold-polymictic and from oligomesotrophic to meso-eutrophic, with oxic conditions at the bottom surface (7.6 ppm of dissolved oxygen) (Mühlhauser et al. 1995).

The sedimentary infill of Lago Chungará was characterized by the lithological description of cores obtained in 2002 (Sáez et al. 2007) and by seismic imagery (Valero-Garcés et al. 2000). It has a minimum thickness of $10 \mathrm{~m}$, is largely made up of offshore diatomaceous deposits intercalated with numerous thin tephra layers (lapilli and ashes from the the eruptions of the Parinacota volcano) and some thin carbonate layers and laminae (Sáez et al. 2007). From the bottom to the top of the offshore core, two sedimentary units (Units 1 and 2) were identified and correlated in the basin mainly using tephra keybeds. Every lithological unit was, in turn, subdivided in two subunits (Subunits 1a, 1b, 2a and 2b). Basal Unit 1a, with a thickness ranging between $2.56 \mathrm{~m}$ and $0.58 \mathrm{~m}$, is made up of finely-laminated green and whitish diatomite. Unit $1 \mathrm{~b}$ (up to $1.87 \mathrm{~m}$ in thickness) is composed of laminated and massive brown diatomite with carbonate-rich intervals. Unit 2a (up to $3.44 \mathrm{~m}$ in thickness) is made up of brown massive diatomite with carbonate-rich intervals and volcaniclastics. The sediments of the uppermost Unit $2 \mathrm{~b}$, with a thickness ranging between 3 and $0.86 \mathrm{~m}$, are dark grey to black diatomites with abundant volcaniclastic layers (Sáez et al. 2007).

\section{Materials and Methods}

Fifteen Kullemberg cores (up to $8 \mathrm{~m}$ long) were recovered from Lago Chungará using a raft. Just after the coring all the cores were cut in $1.5 \mathrm{~m}$ sections. In the lab, and prior to the splitting of the sections, physical properties (GRAPE-density, p-wave velocity and magnetic susceptibility) were measured using a GEOTEK ${ }^{\mathrm{TM}}$ MultiSensor Core Logger (MSCL) every centimeter. The sections were then split longitudinally and accurate lithological profiles were made.

According to the results of the stratigraphic cross sections of an earlier study (Sáez 
et al. 2007), cores 10 and 11, located in the offshore zone, were selected for the paleoenvironmental reconstruction. A composite core was constructed using both cores in order to record the whole sedimentary infill in the offshore zone of the lake. This composite core corresponds to the lithological units 1 and 2 defined previously (Sáez et al. 2007). This composite core will henceforth be referred to as core in the text.

The best preserved half core of every section was digitised using a CCD camera. The digital photographs obtained were intercalibrated and the gray curve was calculated using the ImageJ software package (Rasband 1997-2004). The gray values were obtained every $0.1 \mathrm{~mm}$. These sections were also employed for XRF (X-Ray Fluorescense) analyses using the new generation XRF core scanner from the University of Bremen. Eight light (Al, Si, S, K, Ca, Ti, Mn and Fe) and six heavy (Rb, Sr, Zr, Sn, Te and Ba) elements were measured. The light elements were determined every $2 \mathrm{~mm}$ and the heavy ones, every $10 \mathrm{~mm}$. Each measurement was counted using the following conditions: $60 \mathrm{~s}, 10 \mathrm{kV}$ and $1 \mathrm{~mA}$ to obtain statistically significant data (see Moreno et al. (2007) for further details). Samples for x-ray diffraction were retrieved every $5 \mathrm{~cm}$, dried at $60{ }^{\circ} \mathrm{C}$ for 24 hours and manually ground using an agate mill. X-ray diffractions were performed using an automatic Siemens D-500 X-ray diffractometer in the following conditions: $\mathrm{Cu} k \alpha, 40 \mathrm{kV}, 30$ $\mathrm{mA}$, and graphite monochromator. The X-ray diffraction patterns revealed that the samples were composed of two fractions: a crystalline fraction (highlighted by different peaks) and an amorphous one (characterised by the presence of a broad peak centered between $20^{\circ}$ and $25^{\circ} 2 \theta$ ). The identification and quantification of the different mineralogical species present in the crystalline fraction were carried out following a standard procedure (Chung 1974). The area of the amorphous fraction was calculated as total counts using the software attached to the X-ray diffractometer. A logarithmic function allowed us to convert the total counts to area of the amorphous fraction as the percentage of the total weight of the sample (Moreno et al. 2007).

Samples for Total Organic (TOC), Total Inorganic (TIC) and Total Carbon (TC) determinations were retrieved every five centimetres. TC and TIC were determined using a UIC model $5011 \mathrm{CO}_{2}$ Coulometer, and TOC content was measured by substraction. Samples for Total Biogenic Silica (TBS) determinations were also retrieved every five centimetres. TBS was extracted using the alkaline leaching technique by Mortlock and Froelich (1989) and measured by a molybdate blue spectrophotometric technique (Hansen and Grashoff 1983) using an AutoAnalyser Technicon AAII.

The chronological framework of the sedimentary sequence of Lago Chungará was constructed using 17 radiocarbonic AMS (Table 1) and one ${ }^{238} \mathrm{U} /{ }^{230}$ Th date (Table 2). The radiocarbon dates were performed in the Arizona Radiocarbon Laboratory (USA) and in the Poznan Radiocarbon Laboratory (Poland) whereas the ${ }^{238} \mathrm{U} /{ }^{230} \mathrm{Th}$ dates were carried out using a ICP-IRMS multicollector at the University of Minnesota (Edwards et al. 1986). The Dissolved Inorganic Carbon (DIC) from the surface water of the lake was dated at the Beta Analytics Inc. Laboratory in order to determine the present day reservoir-effect, and an apparent age of 2,320 \pm 20 years BP was obtained. This apparent reservoir-effect age was corrected to remove the effects of the thermonuclear bomb tests carried out during the 1950s and 1960s (see below for a detailed discussion). The calibration of the radiocarbon dates was performed using the CALIB 5.02 software and the INTCAL98 curve (Stuiver et al. 1998; Reimer et al. 2004a). The software described in Heegaard et al. (2005) was employed to construct a 
reliable age-depth model, furnishing a final corrected age for each calibrated date. The uppermost sediments of the Lago Chungará were not retrieved due to the Kullemberg coring system. This have provoked that the last approximately 1000 years BP were not studied in the present work (see Sáez et al. (2007) for further details).

The statistical treatment of the datasets was performed using the R software package (R Development Core Team 2007) together with the packages "gclus” (Hurley 2004) for clustering purposes and "vegan” (Oksanen et al. 2005) for Redundancy analyses. At each stage, distances between clusters were recomputed by the Lance-Williams dissimilarity update formula according to the particular clustering method used (Kaufman and Rousseeuw 1990). The clustering method employed was the complete linkage method which uses the largest dissimilarity between a point in the first cluster and a point in the second cluster (furthest neighbor method) to build the dissimilarity tree.

\section{Results}

\section{Mineralogical (XRD) and geochemical (XRF) composition of the sediments}

The offshore sediments of Lago Chungará are composed of an amorphous and a crystalline fraction. The amorphous fraction, made up of organic matter and diatoms, range from $40 \% \mathrm{wt}$ (towards the top of the composite core) to almost $100 \% \mathrm{wt}$ (from the lower two thirds of the composite core towards its bottom) of the total weight of the sample. The crystalline fraction, ranging between less than $1 \% \mathrm{wt}$ and $60 \% \mathrm{wt}$, is composed of Ca-plagioclase, carbonate (calcite and dolomite), muscovite, pyrite, quartz and an amphibole (probably riebeckite). Three zones were defined on the basis of compositional criteria and labelled from the bottom to the top of the sequence (Figure 2) as follows:

- Zone 3: Ranges from the bottom of the core to $3500 \mathrm{~mm}$ of core depth. It is $5000 \mathrm{~mm}$ thick, and is dominated by amorphous material (more than $95 \%$ of the total weight of the sample). Ca-plagioclase, quartz and pyrite are the main mineral species present in the crystalline fraction.

- Zone 2: Ranges from $3500 \mathrm{~mm}$ to $1000 \mathrm{~mm}$ of core depth, and is characterized by the highest percentages of calcite. From $2000 \mathrm{~mm}$ of core depth towards the top, the percentages of the plagioclase increase whereas those of the amorphous fraction decrease.

- Zone 1: Ranges from $1000 \mathrm{~mm}$ of core depth to the top. This zone is characterised by the highest percentages of Ca-plagioclase.

The geology of the Lago Chungará catchment (see Sáez et al. (2007) for further details) indicates that plagioclases, quartz, amphibole and muscovite have two main provenances: a) the erosion of former volcanic rocks and of previous deposited fallout material from the catchment, and b) the ash fallout from the Parinacota volcano. The macroscopic characterization of the tephra layers in the sediments of Lago Chungará revealed that they consist on ash and lapilli. Hence, the input of volcaniclastic material eroded from former volcanic rocks could constitute a minor percentage with respect to the direct fall of volcaniclastic material from the Parinacota volcanic eruptions. On the other hand, the origin of the carbonates is not so obvious. The presence of large amounts of $\mathrm{Ca}$ of volcanic origin dissolved in the water of the lake 
together with an important lake level decrease, evidenced by a sudden increase of benthic diatoms (Sáez et al. 2007), could promote the precipitation of these carbonates.

The downcore profiles of heavy and light elements analyzed by XRF scanner mark three different zones in terms of their geochemical composition (Figure 3):

- a lower zone (from $4500 \mathrm{~mm}$ of core depth to the bottom of the core) characterised by the highest Si content (see Moreno et al. (2007) for further details).

- an intermediate zone (from $1000 \mathrm{~mm}$ to $4500 \mathrm{~mm}$ of core depth) with the highest Ca values, and

- an upper volcanic-rich zone (which ranges from the top of the core up to 1000 $\mathrm{mm}$ of core depth) with maximum values in almost all elements.

Zone 1 defined in the mineralogical profile and the upper zone defined by XRF analyses (Figures 2 and 3 respectively) corresponds to the same core interval (the uppermost meter of the core). On the contrary, the limit of the mineralogical zones 2 and 3 (located at $3500 \mathrm{~mm}$ of core depth in the Figure 2) and the limit between the intermediate and lower XRF zones (situated at $4500 \mathrm{~mm}$ of core depth in the Figure 3 ) do not correspond. This absence of correspondence could be attributed to the different methodologies used to characterize the presence of diatoms and other amorphous material (amorphous material in the X-ray diffraction diagram and $\mathrm{Si}$ in the XRF diagram). The detailed characterization of the XRF zones and their geochemical implications are discussed in detail in Moreno et al. (2007).

\section{Statistical Analyses \\ Construction of the dataset}

The identification and characterization of the forcings that trigger the sedimentary infill of Lago Chungará were carried out by applying statistical analyses to magnetic susceptibility, XRF, XRD, TC, TOC, TBS and gray-colour curve data. Every proxy had a different sampling interval: the light XRF elements were determined every 2 $\mathrm{mm}$, the heavy XRF elements every $10 \mathrm{~mm}$, the mineralogical composition, TC, TOC and TBS every $50 \mathrm{~mm}$ and the gray-color every $0.1 \mathrm{~mm}$. Hence, all the variables were linearly interpolated with a regular spacing of $2 \mathrm{~mm}$, in order to retain the maximum information from the XRF, and were normalised in order to avoid problems arising from their different orders of magnitude. An initial dataset of 28 variables per 3,909 samples was constructed. To test the robustness of the interpolation, correlation coefficients among the different variable as well as Principal Component Analysis were performed on a subdataset of values taken at the coarsest sampling resolution (i.e. $50 \mathrm{~mm}$ ). The results were compared with those obtained from the $2 \mathrm{~mm}$ interpolated dataset. The strong coincidence between both results (not shown) indicate that the statistical analyses provided in this paper are robust.

\section{Redundancy Analyses}

Redundancy Analyses (RDA) were carried out given that many variables of the dataset represent similar aspects of the geochemical composition of the sediments (Figure 4). The mineralogical composition of the sediments was used as a 
constraining matrix given that each mineralogical species represents a "compendium" of geochemical elements. Thus, RDA was used to identify the possible provenances of the light and heavy elements obtained by XRF, and the other geochemical parameters (TC, TOC, TBS, magnetic susceptibility and gray-colour curves).

RDA analysis allowed us to define five main "families" of variables in accordance with their possible origin (Figure 4):

- Family A: Most of the light and heavy elements (Fe, Ti, Rb, K, Ba, Zr, Al and Sr) had a volcanic origin given that they were grouped with the plagioclase and the amphibole. The magnetic susceptibility data were also associated with the volcanic material.

- Family B: Located opposite to Family A is Family B constituted by TBS and amorphous material. Variations in the diatom content could be the main factor responsible for this second family.

- Family C: The "carbonate family" is made up of Ca and TC. According to the Figure 2 almost all TC corresponds to TOC. This suggests that the organic matter (as a indicator of biological activity) plays an important role in the precipitation of carbonates. The presence of quartz in this family indicates that a percentage of these carbonates could have precipitated in the shallow littoral areas of the lake and, subsequently, remobilized and transported to deep offshore areas. TOC seems to play an intermediate role in families B and C. This seems reasonable given that the organic matter is one of the main components in both families.

- Family D: Opposite to Family C there is a group of variables composed of Si, $\mathrm{S}$ and Sn, forming Family D. The two main sources of silicium and sulphur are related to the volcanic material and diatoms. Hence, this family occupies intermediate positions between Families B and A. The origin of Sn is unclear.

- Family E: Family E is composed of pyrite and Mn. SEM observations highlighted the presence of framboids of pyrite between the frustules of the diatoms and their relation to the Mn content as minor element. Thus, this family would represent some early diagenetic processes related to $\mathrm{Eh} / \mathrm{pH}$ changes within the sediment.

According to the RDA analysis, the dataset was simplified to 17 variables (Amorphous, TBS, magnetic susceptibility, gray-colour curve, S, Si, Al, Ba, K, Zr, Rb, Ti, Fe, Sr, Ca, TC and TOC).

\section{Stratigraphically-unconstrained Cluster Analysis}

This analysis groups the samples in accordance with their affinity. The samples that have similar geochemical and mineralogical features are plotted close to each other, whereas those samples that present a very distinctive geochemical and mineralogical signature are plotted at the very ends of the tree. Hence, the stratigraphicallyunconstrained cluster analysis allows us to identify the main geochemical and mineralogical families. According to this statistical analysis, three main geochemical and mineralogical groups of samples were identified (Figure 5) (1) the "volcanic" group (samples dominated by volcanic material), (2) the "non-volcanic" group (samples mainly composed of organic matter and diatoms) and (3) the "outsiders". Furthermore, two kinds of "outsider" samples were identified:

- Isolated samples that present an "anomalous" value in one variable 
(commonly one variable from the XRF analyses). These samples are distributed throughout the sequence. The visual inspection of the lithological section of the core corresponding to these "anomalous" samples did not reveal any remarkable features. Hence, these anomalies were interpreted as anomalous acquisitions of the XRF scanner and they were eliminated from the dataset.

- Groups of contiguous samples showing abrupt values changes in almost all variables compared to those located immediately upwards and/or downwards. These samples are located in the uppermost $3500 \mathrm{~mm}$ of the core, except two samples located at 6806 and $6808 \mathrm{~mm}$ of core depth. The number of samples that constitutes these groups range between 2 (e.g. 2047 - $2049 \mathrm{~mm}$ ) and 41 (2305 - $2461 \mathrm{~mm}$ ). In all cases, these groups correspond to the uppermost part of the volcanic tephra layers. This geochemical and mineralogical signature was interpreted as tephra deposits that differed from the volcanic material present throughout the sedimentary infill. According to Wörner et al. (1988), the main source of volcanic material present in Lago Chungará was related to the emplacement of Parinacota volcano. At ca. 6,000 cal years BP, two Parinacota satellite cones started their eruptive activity. The geochemical composition of the lava flows of the Ajata cones is different (greater abundance of mafic minerals and absence of plagioclases) from that of the Parinacota volcano (Wörner et al. 2000). The groups of samples isolated by the stratigraphically-unconstrained cluster analyses could represent the tephra deposits proceeding from the eruptive activity of the Ajata satellite cones. Such groups of samples were also removed from the dataset.

\section{Principal Component Analyses (PCA)}

Finally, a dataset of 17 variables and 3,770 samples was created. Principal Component Analysis (PCA) was carried out using this final dataset. This analysis was used to highlight the main underlying processes that trigger the input, distribution and sedimentation of particles in the Lago Chungará offshore deposits.

The first two eigenvectors accounted for $65.81 \%$ of the total variance. The first eigenvector represented $50.22 \%$ of the total variance, and this eigenvector was controlled mainly by the light and heavy elements at the positive end, and partially by amorphous material and TBS at the negative end (Figure 6). On the other hand, the second eigenvector accounted for $15.59 \%$ of the total variance, and was controlled by the presence of TOC, TC, gray-colour curve and $\mathrm{Ca}$ at the positive end and by $\mathrm{Si}$ and $\mathrm{S}$ and, in minor proportion, by TBS and amorphous material at its negative end (Figure 6). In fact, family B occupies an intermediate position contributing to both eigenvectors.

The other eigenvectors defined by the PCA analysis were not taken into account given that they explain progressively lower percentages of the total variance (the other fifteen eigenvectors only accounted for $12 \%$ of the total variance).

\section{Construction of the chronological framework for the Lago Chungará sequence}

Obtaining radiometric dates to construct a robust and reliable chronological 
framework for the sediments of Lago Chungará was very complicated owing to the scarcity of suitable material, whether terrestrial organic rests or pure calcite crystals. Seventeen AMS ${ }^{14} \mathrm{C}$ dates were obtained from (1) bulk organic matter from the central plain cores and (2) aquatic organic macrorests picked from littoral cores (Table 1). Other 17 samples of calcite were employed for ${ }^{238} \mathrm{U} /{ }^{230} \mathrm{Th}$ dating.

Most of the ${ }^{238} \mathrm{U} /{ }^{230} \mathrm{Th}$ dates were discarded due to their high ${ }^{232} \mathrm{Th}$ content, indicative of high terrigenous particles (Table not shown). Only one ${ }^{238} \mathrm{U} /{ }^{230} \mathrm{Th}$ date located at $3,440 \mathrm{~mm}$ of core depth (Table 2) was coherent with the reservoir-corrected ${ }^{14} \mathrm{C}$ model (Moreno et al. 2007; Sáez et al. 2007). On the other hand, two radiocarbon dates (AA56905 and Poz-8725) were also discarded because they were clearly reversed, probably due to sedimentary reworking processes. Both dates are located in the upper part of the Unit 1a. The three other samples (Poz-8723, AA56903 and Poz8724) from the volcanic-rich Unit $2 \mathrm{a}$ are consistent with one and other. They are older than the radiocarbon dates of the Units $2 b$ and $1 b$, show no evidence of depositional reworking, and are older than the only reliable ${ }^{238} \mathrm{U} /{ }^{230} \mathrm{Th}$ radiometric date. It is worth noting that the activity of the Parinacota volcano started during the deposition of this sedimentary unit. Hence, one possibility is that the volcanic activity could have altered the $\mathrm{CO}_{2}$ balance among the different sources, modifying the ${ }^{14} \mathrm{C}$ value of these three samples (Moreno et al. 2007). A similar effect has been documented in other lakes from the Altiplano (Valero-Garcés et al. 1999) and it has been considered as a source of anomalous ${ }^{14} \mathrm{C}$ dates in some volcanic lakes from the Azores Islands (Björck et al. 2006). These three radiocarbon dates were initially retained in order to construct the final chronological framework for the Unit 2a (Table 1).

Other problems that hamper the construction of a reliable chronological framework are (1) the assessment of the large and variable radiocarbon reservoir effect that influences most lake deposits in the Andean Altiplano (Geyh et al. 1999; Geyh and Grosjean 2000; Grosjean etal. 2001), and (2) the temporal evolution of this radiocarbon reservoir effect. The radiocarbon dating of the modern dissolved inorganic carbon (DIC) resulted in 2,320 $\pm 40{ }^{14} \mathrm{C}$ years BP (Table 1 ), but this value must be corrected due to the atmospheric thermonuclear bomb tests carried out during the late 1950s - early 1960s. These nuclear tests doubled the amount of ${ }^{14} \mathrm{C}$ in the atmosphere (Reimer et al. 2004b). The modern reservoir effect in lakes must be calculated as the difference between the ${ }^{14} \mathrm{C}$ age of the water and of the atmospheric ${ }^{14} \mathrm{CO}_{2}$ measured at the same time (Goslar comm. pers.). The effects of these thermonuclear bomb tests in the modern carbon cycle of a lake depends on (1) the year that the sample was taken and (2) the residence time of the lake. The Lago Chungará water residence time is about 15 years (Herrera et al. 2006) and the DIC sample was obtained and dated in 2004, therefore, the real present-day reservoir effect of this lake is 3,260 years BP (2,320 years BP (radiocarbon date of the DIC) minus -920 years (apparent radiocarbon age of the atmospheric ${ }^{14} \mathrm{CO}_{2}$ for the period 2002 - 1988)) (Hua and Barbetti 2004; Goslar et al. 2005), a value close to that obtained by Geyh et al. (1999). The reservoir effect in the Altiplano lakes proved to be highly variable over time. One of the factors that could influence the reservoir effect is the change in the volume/surface ratio of the lake, which is a function of the water depth (Geyh et al. 1998; Grosjean et al. 2001). According to these authors the reservoir effect decreases when the lake level diminishes, and vice versa. This lake level - reservoir effect correlation has been described in Laguna Lejía (Geyh et al. 1998), in Laguna Miscanti (Geyh et al. 1999; Grosjean et al. 2001), and specifically 
for Lago Chungará (Geyh and Grosjean 2000).

Therefore, the approach followed in Moreno et al. (2007) and in this study to correct the dates for the variable reservoir effect was based on two assumptions: (1) the Lago Chungará ecosystem had an environmental status during deposition of Unit 2b similar to that currently found and (2) the present-day lake level is at its highest. Accordingly, a different correction of the reservoir effect was applied to Units 1 and 2.

Unit 2 is made up of dark gray massive diatomaceous oozes with abundant volcanic layers, whereas Unit 1 is mainly characterized by laminated sediments without volcanic input. This different pattern allowed us to consider a constant reservoir effect for Unit 2 since the average lake characteristics most likely did not vary much over time (Moreno et al. 2007). A constant reservoir effect of 3,260 years was subtracted from the radiocarbon dates present in this unit. It is only possible to hypothesize about the variations over time of the reservoir effect in Unit 1. In accordance with the hypothesis advanced by Geyh et al. (1998), the reservoir effect was probably lower in Unit 1 than in Unit 2 since the lake was, on average, shallower than during the deposition of the upper unit (Sáez et al. 2007). Since it was not possible to estimate the reservoir effect by applying the methodology established by Geyh et al. (1998), the ages of the two extreme reservoir values (a minimum of 0 and a maximum of 3,260 years) were calculated (Table 1). All the corrected radiocarbon dates were calibrated using the CALIB 5.02 software package (Reimer et al. 2004a) selecting the mid-point of $95.4 \%$ of the distribution.

The upper and lower limits of the chronological model were calculated employing the Cagedepth software (Heegaard et al. 2005). Therefore, the column "Calibrated age calendar years BP" of Table 1 refers to the corrected and calibrated radiocarbon dates considering a constant reservoir effect of 3,260 years (dotted line in Figure 7) whereas the column "Calibrated age calendar years BP" shows the non-corrected reservoir effect and calibrated radiocarbon dates (Table 1 and dashed line in Figure 7). A theoretical mid point between the two extreme reservoir effect points were calculated for Unit 1 and this theoretical value was employed to construct the final chronological model. The final age-depth model can be seen in Figure 7 (intermediate continuous line). The corrected ${ }^{14} \mathrm{C}$ dates of the Subunit 2a using the proposed method by Heegaard et al. (2005) are consistent with the only ${ }^{238} \mathrm{U} / 230 \mathrm{Th}$ retained date, validating this correction.

\section{Discussion}

\section{Sedimentological significance of the Eigenvectors}

The X-ray diffractions showed that the main minerals are related to the volcaniclastic deposits. Furthermore, the RDA analysis also revealed that (1) most of the analysed geochemical elements have the same origin, and (2) are related to the Ca-plagioclase. Hence, the first eigenvector of the PCA analysis indicated changes in the volcanic content in the sediments. High values of the first eivenvector will point to the presence of tephra layers whereas low values will indicate the presence of diatomiterich sediments.

The interpretation of the second eigenvector is less clear. Total silica has been widely used as proxy for siliceous microfossils such as diatoms, chrysophycean cysts, sponges and phytoliths (Conley and Schelske 2001) as well as for inorganic 
components such as siliceous minerals. The total silica content in the Lago Chungará sediments was determined by a wet chemical digestion (TBS), X-ray diffraction (amorphous material) and an XRF scanner (Si). TBS has been widely employed as a good proxy for siliceous microfossil content (Conley and Schelske 2001) whereas Si is an indicator of the presence of silica particles of both organic and inorganic origin. In fact, the presence of two subgroups of variables ( $\mathrm{Si}$ and $\mathrm{S}$ on the one hand, and TBS and amorphous material in a minor proportion on the other hand) at the negative end of the second eigenvector could be interpreted as indicative of the presence of particles from two different sources, organic (diatoms) and inorganic (mainly clay and pyrite). TC and TOC are indicative of the presence of organic matter remains, and $\mathrm{Ca}$ could be associated with the existence of calcium carbonates (as suggested by the RDA analysis). Hence, the second eigenvector would reflect changes in the organic matter, carbonates, and diatoms. This alternance is clearly visible in the lower laminated Unit 1 (Sáez et al. 2007).

Variations along this second eigenvector could be interpreted as changes in water availability. These changes in water availability would be a direct consecuence of effective regional precipitation - evaporation variations. More rainfall in the lake catchment would imply more runoff (more erosion of the soils), and then, a higher nutrient input into the lake. This higher nutrient input would allow enhanced diatom blooms. By contrast, low rainfall values would imply low runoff coefficients in the lake catchment, and hence, diminished diatom blooms. Furthermore, low precipitation values would also lead to falls in the water level, resulting in an increase in water salinity and in carbonate precipitation.

In summary, the PCA analysis showed that the main processes that control the input and infill of Lago Chungará are closely related to the volcanic activity of the surrounding volcanoes (first eigenvector). On the other hand, the processes related to changes in water availability are highlighted in the second eigenvector.

\section{Temporal reconstruction of the volcanic input and of water availability in Lago Chungará}

The location of every sample with respect to the new vectorial spaces defined by PCA (in other words, their xy coordinates) indicates a specific position with respect to the volcanic input and the water availability processes, respectively. All samples located at the positive end of the first eigenvector (high values of the x-coordinate and low values of the $y$-coordinate) are composed of volcanic material, and viceversa. The same is true for those samples located at the positive or negative end of the second eigenvector, but with respect to water availability. Hence, the plot of the $\mathrm{x}$ - and $\mathrm{y}$ coordinates of every sample with respect to their core depth will allow us to qualitatively reconstruct the evolution of the input of the volcanic material (Figure 8) and that of water availability (Figure 9).

According to the chronological framework, it has been possible to reconstruct the input of the volcanic material and the water availability variations for the last 12,300 cal. years BP.

\section{Eruptions history of the Parinacota volcano in the}




\section{Lago Chungará sedimentary sequence}

The plot of the $\mathrm{x}$-coordinates of the samples with respect to their age allowed us to reconstruct the volcaniclastic input in Lago Chungará (Figure 8). All this volcaniclastic material originated from the different eruptions of the Parinacota volcano and its satellite cones on the northern shore of the lake. Parinacota and its satellite cones have been the only active volcanoes in the area in the last 14,500 years (DeSilva and Francis 1991).

Two main periods can be established in accordance with the evolution of the volcaniclastic input to the lake:

1. From ca. 12,300 cal yr BP to ca. 7,800 cal yr BP: During this period the volcaniclastic input to the lake was low, with a slight tendency to decrease towards the latest stages of the Early Holocene. Only a thin tephra layer, dated at ca. 11,000 cal yr BP and identified as M1 in Sáez et al. (2007), was deposited within the lake. SEM observations carried out in the lower laminated sediments showed that volcaniclastic particles were distributed fairly homogeneously within the sediments, which suggests that this volcanic material was constantly incorporated into the lake. This continuous input to the lake can be interpreted (1) as erosion of the earlier deposited volcanic material in the catchment area, and (2) as a direct input of minor Parinacota volcano eruptions which did not form tephra layers. The Chungará river as well as the other minor effluents could be the responsible for this. In any case, this riverine supply should not be interpreted as large fluvial deposits but as plume suspended material. The presence of shards and of terrigenous volcanic particles in the sediments support both these interpretations.

2. From ca. 7,800 cal yr BP to ca. 1,000 cal yr BP. This period was characterised by a marked increase in the input of volcanic material to the lake when several large eruptions of the Parinacota volcano deposited, at least, 10 ash-layers (labelled from M2 to M11 according to Sáez et al. (2007)) in about 6,800 years. ${ }^{39} \mathrm{Ar} /{ }^{40} \mathrm{Ar}$ dates performed in the lavas of the Parinacota volcano indicate that this cone was built within the last 5,000 years (Hora et al. 2007). The volcanic input reconstruction suggests that the construction of the present day cone started earlier than 5,000 cal. yr BP. The maximum activity of the Parinacota volcano ended at ca. 2,100 cal yr BP with the deposition of the last identified tephra layer (M11 according to Sáez et al. (2007)). After this maximum, the volcanic activity decreased slightly, and from ca. 2,100 cal yr BP to $c a .1,000$ cal yr BP it remained constant.

The eruptions of the Paricanota volcano affected both Lago Chungará and its surroundings. A comparison of the reconstruction of the volcaniclastic input in Lago Chungará with the record of dust particles exceending $63 \mu \mathrm{m}$ from the Nevado Sajama ice core (Thompson et al, 1998) shows a similar evolution (Figure 8). The dust particle record from the Nevado Sajama shows a marked increase at $c a$. 7,500 cal yr BP, coinciding with the onset of the large explosive period of the Parinacota volcano recorded in the Lago Chungará. This suggests that these particles do not correspond to dust particles eroded during the dry periods, as reported previously (Thompson et al. 1998), but to volcaniclastic particles deposited in the Nevado Sajama during the major explosive eruptions of the Parinacota volcano. Furthermore, it should be pointed out that the volcaniclastic record of the Lago Chungará indicates a much more complex volcanic history in this area than has been suggested (Wörner 


\section{Regional integration of the reconstruction of Lago Chungará water availability}

It has not been possible to date to precisely constrain the chronology of the lower half of the Lago Chungará record owing to the difficulty of establishing the precise reservoir-effect correction for the radiocarbon dates of Unit 1. Given these chronological limitations, the reconstruction of the water availability of Lago Chungará was compared with some of the closest paleoenvironmental records of Paco Cocha (Abbott et al. 2003), Lake Titicaca (Tapia et al. 2003; Baker et al. 2001b), and Salar de Uyuni (Baker et al. 2001a) in order to obtain a general regional picture of the evolution of the water availability during the Late Glacial and the Holocene (Figure 9). A comparison of these four paleoenvironmental records shows that the water availability in the northern Chilean Altiplano followed a heterogeneous spatial and temporal pattern. This complexity has also been pointed out by other authors (Abbott et al. 2003; Grosjean et al. 2003; Latorre et al. 2003; Placzek et al. 2006). This comparison has been focussed in three key temporal intervals: Late Glacial - Early Holocene, Mid Holocene and Late Holocene.

\section{Late Glacial - Early Holocene}

The final stage of the Late Glacial period is constituted by the the Coipasa (13,000 11,000 cal years BP) humid phase (Argollo and Mourguiart 2000; Placzek et al. 2006). Although the Coipasa phase has been described as ending at 11,000 cal years BP (Placzek et al. 2006), this humid phase ended much earlier (ca. 11,600 cal years BP) in Lake Titicaca and Salar Uyuni. On the other hand, the paleohydrological reconstruction of Lago Chungará shows that this period was characterized by high lake level stands, with some minor dry oscillations, and it lasted up to ca. 10,900 cal years BP, like in the Río Salado basin (9,600 cal years BP) (Latorre et al. 2006), whereas the Coipasa phase in Paco Cocha ended much more earlier (at about 12,300 cal. years BP). Therefore, the end of this humid phase followed a heterogeneous spatio-temporal pattern (Figure 9). This heterogeneous pattern has also been highlighted by other authors (Latorre et al. 2003).

The end of the Late Glacial and the onset of the Holocene, characterized by the end of the Coipasa humid phase, triggered a fall in the water availability in the region, and hence, the sharp fall in the water levels of Lake Titicaca (Baker et al. 2001b). This dry period affected the ecosystems differently. The water level of Lake Titicaca fell sharply at least $85 \mathrm{~m}$ below the modern lake level and this dry spell lasted approx. 1,000 years (Tapia et al. 2003) whereas the lake level of Paco Cocha remained low from approx. 12,000 cal years BP until 8,000 years BP (Abbott et al. 2003). On the other hand, the water availability in the Lago Chungará area followed a progressive decrease, quite similar to that followed by the Salar Uyuni (Baker et al. 2001a) (Figure 9).

\section{Mid Holocene}

The four paleoclimate records show that the arid period of the Mid Holocene, 
between the $c a$. 8,000 cal years BP and the 4,000 cal years BP, which has been described in many other works (Valero-Garcés et al. 1996; Schwalb et al. 1999; Grosjean et al. 2001, 2003; Latorre et al. 2006), is in fact a succession of dry and humid abrupt episodes as many authors have previously stated (Figure 9). The timing and intensity of such episodes are reflected differently by each lake. The driest period in Paco Cocha occurred between ca. 7,000 and 4,800 cal years BP and lasted for almost 2,000 years, whereas in Lake Titicaca it took place earlier, between 6,600 and 5,000 cal years BP with a duration of $c a$. 1,600 years, and in Lago Chungará occurred between $\mathrm{ca}$. 7,400 and 6,600 cal years BP, lasting for approx. 800 years. Salar Uyuni displayed the driest conditions between ca. 6,500 and 4,200 cal years BP (Baker et al. 2001a). These variations could be attributed to the size, lake morphology, catchment size and lacustrine ecosystem responses to these abrupt episodes. The differential response to these abrupt water availability changes hampers the identification of clear spatial and temporal moisture patterns.

\section{Late Holocene}

The last 4,000 cal years $\mathrm{BP}$ were characterized by a general return to moist conditions, probably related to enhanced precipitation, decreased evaporation, a shorter dry season or a combination of these factors (Marchant and Hooghiemstra 2004). This resulted in (a) an overall rise in lake water levels due to the prevalence of the summer precipitation as a result of the southwards displacement of the InterTropical Convergence Zone (ITCZ) (Argollo and Mourguiart 2000; Marchant and Hooghiemstra 2004), and (b) in a reduction in the intensity of dry spells. Lake Titicaca showed a rise in its lake level and a decline in the intensity of arid crises (Rowe et al. 2003; Tapia et al. 2003) whereas Lago Chungará and Paco Cocha followed a high oscillating lake level pattern with recurrent lake level falls. The evolution of Salar de Uyuni showed an overall trend of lake level increase punctuated with minor lake level decreases (Baker et al. 2001a) (Figure 9). The correlation of some of the falls in lake level in the four lacustrine ecosystems suggests that these falls could be related to the dry spells that affected this region.

\section{Conclusions}

Statistical analyses allowed us to characterize the Parinacota volcano explosive activity and the regional water availability oscillations as the two main forcings that triggered the environmental evolution of Lago Chungará in the last 12,300 years.

The stratigraphically-unconstrained cluster analyses allowed us to identify the "outsiders" of the database. These "outsiders" were regarded as (1) punctual “anomalous” values due to erroneous XRF acquisitions and (2) as ash layers with a different geochemical composition, and hence a different origin. The Principal Component Analyses (PCA) enabled us to distinguish the two main forcings controlling the sedimentary infill of Lago Chungará. The volcanic activity of the Parinacota volcano was the most important forcing (first eigenvector) whereas water availability was the second most important forcing (second eigenvector). A qualitative reconstruction of both forcings was carried out by plotting the PCA x(volcanic input) and y-coordinates (water availability) of all samples with respect to their core depth.

The temporal evolution of the volcanic input to the lake showed that this input 
increased with time. Two main periods can be distinguished: from 12,300 to 7,800 cal years BP, characterized by the partial absence of volcanic eruptions, and, from 7,800 to 1,000 cal years BP, during which the volcaniclastic material from the eruptions of the Parinacota volcano increased markedly. The proximity of the Parinacota volcano and the close correlation of the dust particles of the Nevado Sajama ice core and the tephra stratigraphy of Lago Chungará sedimentary record suggest that the dust particles present in the ice core originated from the major explosive eruptions of the Parinacota volcano.

Comparison of the reconstruction of the water availability of Lago Chungará with the paleoenvironmental reconstructions of Paco Cocha (Abbott et al. 2003), Lake Titicaca (Tapia et al. 2003; Rowe et al. 2003) and Salar de Uyuni (Baker et al. 2001a) highlighted the heterogeneous temporal and spatial pattern of precipitation. Despite showing a quite close correlation, each lacustrine ecosystem responded differently to the moisture oscillations. The variations in the paleoenvironmental records could be attributed to the size, lake morphology, catchment size, lacustrine ecosystem responses to the abrupt arid episodes and uncertainities in dating.

\section{Acknowledgements}

We are indebted to D. Schnurremberger, M. Shapley and A. Myrbo of the Limnological Research Center staff for their field assistance during the coring campaign. Larry Edwards (University of Minnesota) and Rogert O. Gibert (University of Barcelona) are thanked for the ${ }^{238} \mathrm{U} /{ }^{230} \mathrm{Th}$ TIMS dates. This research work was funded by the projects BTE2001-3225, BTE2001-5257-E and GCL200400683 from the Spanish Science and Technology Ministry. We are indebted to Tomasz Golsar (Poznan Radiocarbon Laboratory) for helping with the calculation of the present-day reservoir effect of Lago Chungará and to George von Knorring and an anonymous referee for improving the final version of the paper.

\section{References}

Abbott M, Wolfe B, Wolfe A, et al. (2003) Holocene paleohydrology and glacial history of the central Andes using multiproxy lake sediment studies. Palaeogeogr Palaeoclimatol Palaeoecol 194:123-138

Argollo J, Mourguiart P (2000) Late Quaternary climate history of the Bolivian Altiplano. Quat Int 72:37-51

Baker P, Rigsby C, Seltzer G, et al. (2001a) Tropical climate changes at millennial and orbital timescales on the Bolivian Altiplano. Nature 409:698-701

Baker P, Seltzer G, Fritz S, et al. (2001b) The history of South American tropical climate for the past 25,000 years. Science 291:640-643

Battarbee R (2000) Palaeolimnological approaches to climate change, with special regard to biological record. Quat Sci Rev 19:107-124

Björck S, Rittenour T, Rosén P, et al. (2006) A holocene lacustrine record in the central North Atlantic: proxies for volcanic activity, short-term NAO mode variability, and long-term precipitation changes. Quat Sci Rev 25:932

Camarero L, Catalan J, Pla S, et al. (1995) Remote mountain lakes as indicators 
of diffuse acidic and organic pollution in the Iberian Peninsula (AL:PE2 studies). Water, Air \& Soil Pollution 85:487-492

Carrera G, Fernández P, Grimalt J, et al. (2002) Atmospheric deposition of organochlorine compounds to remote high mountain lakes of Europe. Environ Sci Technology 36:2581-2588

Chung F (1974) Quantitative interpretation of X-ray diffraction patterns of mixtures: II. Adiabatic principles of X-ray diffraction analysis of mixtures. J Appl Crystallogr 7:526-531

Clavero J, Sparks R, Huppert H, et al. (2002) Geological constraints on the emplacement mechanism of the Parinacota debris avalanche, northern Chile. Bull Volcanol 64:40-54

Conley D, Schelske C (2001) Biogenic silica. In: Smol JP, Birks HJB, Last WM (eds) Tracking Environmental Change using Lake Sediments. Terrestrial, Algal and Siliceous Indicators, vol 3, Kluwer Academic Publishers, Dordrecht, pp 281-293

DeSilva S, Francis P (1991) Volcanoes of the Central Andes. Springer-Verlag

Edwards R, Chen J, Wasserburg G (1986) ${ }^{238} \mathrm{U}-{ }^{234} \mathrm{U}-{ }^{230} \mathrm{Th}-{ }^{232} \mathrm{Th}$ systematics and the precise measurements of time over the past 500.000 years. Earth Planet Sci Lett 81:175-192

Fritz S (1996) Paleolimnological records of climatic change in North America. Limnol Oceanogr 41:882-889

Geyh M, Grosjean M (2000) Establishing a reliable chronology of lake level changes in the Chilean Altiplano: are sult of close collaboration between geochronologists and geomorphologists. Zbl Geol Paläont Teil 1:985-995

Geyh M, Grosjean M, Núñez L, et al. (1999) Radiocarbon reservoir effect and the timing of the Late-Glacial/Early Holocene humid phase in the Atacama Desert, Northern Chile. Quat Res 52:143-153

Geyh M, Schotterer U, Grosjean M (1998) Temporal changes of the ${ }^{14} \mathrm{C}$ reservoir effect in lakes. Radiocarbon 40:921-931

Giralt S, Julià R (2003) Water level reconstruction in closed lakes based on the mineralogical composition of sediments, In: Valero-Garcés BL (ed) Limnogeology in Spain: a tribute to Kerry Kelts. Consejo Superior de Investigaciones Científicas, Madrid, pp 305-325

Goslar T, van der Knaap W, Hicks S, et al. (2005) Radiocarbon dating of modern peat profiles: pre- and postbomb ${ }^{14} \mathrm{C}$ variations in the construction of age-depth models. Radiocarbon 47:115-134

Grosjean M, Cartajena I, Geyh M, et al. (2003) From proxy data to paleoclimate interpretation: the mid-Holocene paradox of the Atacama Desert, northern Chile. Palaeogeogr Palaeoclimatol Palaeoecol 194:247-258

Grosjean M, van Leeuwen J, van der Knaap W, et al. (2001) A 22,000 ${ }^{14}$ C year BP sediment and pollen record of climate change from Laguna Miscanti (23S), northern Chile. Glob Planet Change 28:35-51

Hansen H, Grashoff K (1983) Automated chemical analysis In: Grashoff M, Ehrhardt M, Kremlin, K (eds) Methods of Seawater Analysis. Verlag Chemie, Weinheim, pp 368-376

Heegaard E, Birks H, Telford R (2005) Relationships between calibrated ages 
and depth in stratigraphical sequences: an estimation procedure by mixedeffect regression. The Holocene 15:612-618

Hennebert M, Lees A (1991) Environmental gradients in carbonate sediments and rocks detected by correspondence analysis: examples from the Recent of Norway and the Dinantian of southwest England. Sedimentology 38:623-642

Herrera C, Pueyo J, Sáez A, et al. (2006) Relation of surface and underground waters in chungará and cotacotani lake districts, northern Chile: an isotopic study. Rev Geol Chile 33:299-325

Hora J, Singer B, Wörner G (2007) Volcano eruption and eruptive flux on the thick crust of the Andean Central Volcanic Zone: ${ }^{40} \mathrm{Ar} /{ }^{39} \mathrm{Ar}$ constrains from Volcán Parinacota, Chile. Geol Surv Am Bull 119:343-362

Hua Q, Barbetti M (2004) Review of tropospheric bomb ${ }^{14} \mathrm{C}$ data for carbon cycle modeling and age calibration purposes. Radiocarbon 46:1273-1298

Hurley C (2004) gclus: Clustering Graphics. R package version 1.2

Kaufman L, Rousseeuw P (1990) Finding Groups in Data: An Introduction to Cluster Analysis. Wiley, New York

Latorre C, Betancourt J, Rylander K, et al. (2003) A vegetation history from the arid prepuna of northern Chile (22-23 $\left.{ }^{\circ} \mathrm{S}\right)$ over the last 13500 years. Paleogeogr Paleoclimatol Paleoecol 194:223-246

Latorre C, Betancout J, Arroyo M (2006) Late Quaternary vegetation and climate history of a perennial river canyon in the Río Salado basin (22 $\left.{ }^{\circ} \mathrm{S}\right)$ of Northern Chile. Quat Res 65:450-466

Marchant R, Hooghiemstra H (2004) Rapid environmental change in African and South American tropics around 4000 years before present: a review. Earth-Sci Rev 66:217-260

Moreno A, Giralt S, Valero-Garcés B, et al. (2007) Effects of climate, lake productivity and volcanic influences unravelled for last 13000 years in the Central Chilean Altiplano: a high-resolution geochemical study. Quat Int 161:4-21

Mortlock R, Froelich P (1989) A simple method for the rapid determination of biogenic opal in pelagic marine sediments. Deep-Sea Res 36:1415-1426

Mühlhauser H, Hrepic N, Mladinic P, et al. (1995) Water quality and limnological features of a high altitude Andean lake, Chungará, in northern Chile. Revista Chilena de Historia Natural 68:341-349

Oksanen J, Kindt R, O’Hara R (2005) vegan: Community Ecology. Package R version 1.6-9

Pla S, Catalan J (2005) Chrysophyte cysts from lake sediments reveal the submillennial winter/spring climate variability in the northwestern Mediterranean region throughout the Holocene. Clim Dynam 24:263-278

Placzek C, Quade J, Patchett P (2006) Geochronology and stratigraphy of late Pleistocene lake cycles on the southern Bolivian Altiplano: Implications for causes of tropical climate change. Geol Soc Am Bull 118:515-532

Rasband W (1997-2004) ImageJ. National Institutes of Health, Bethesda, Maryland, USA

R Development Core Team (2007) A language and environment for statistical 
computing. R Foundation for Statistical Computing Vienna, Austria ISBN3-900051-07-0

Reimer P, Baillie M, Bard E, et al. (2004a) IntCal04 Terrestrial Radiocarbon Age Calibration, 0 - 26 Cal Kyr BP. Radiocarbon 46:1029-1058

Reimer P, Brown T, Reimer R (2004b) Discussion: reporting and calibration of post-bomb ${ }^{14} \mathrm{C}$ data. Radiocarbon 46:1299-1304

Rodó X, Giralt S, Burjachs F, et al. (2002) High-resolution saline lake sediments as enhanced tools for relating proxy paleolake records to recent climatic data series. Sed Geol 148:203-220

Rowe H, Guildersonc T, Dunbar R, et al. (2003) Late Quaternary lake-level changes constrained by radiocarbon and stable isotope studies on sediment cores from Lake Titicaca, South America. Glob Planet Change 38:273290

Sáez A, Valero-Garcés B, Moreno A, et al. (2007) Lacustrine sedimentation in active volcanic settings: The Late Quaternary depositional evolution of Lake Chungará (northern Chile). Sedimentology. doi: 10.1111/j.13653091.2007.00878.x

Schwalb A, Burns S, Kelts K (1999) Holocene environments from stable isotope stratigraphy of ostracods and authigenic carbonate in Chilean Altiplano lakes. Paleogeogr Paleoclimatol Paleoecol 148:153-168

Stuiver M, Reimer P, Bard E, et al. (1998) INTCAL98 Radiocarbon Age Calibration, 24000-0 cal BP. Radiocarbon 40:1041-1083

Tapia P, Fritz S, Baker P, et al. (2003) A Late Quaternary diatom record of tropical climatic history from Lake Titicaca (Bolivia / Perú). Palaeogeogr, Palaeoclimatol Palaeoecol 194:139-164

ter Braak C (1987) Ordination. In: Jongman RHG, ter Braak CJF, van Tongeren OFR (eds) Data Analysis in Community and Landscape Ecology, Centre for Agricultural Publishing and Documentation (Pudoc), Wageningen, pp 91-173

Thompson L, Davis M, Thompson E, et al. (1998) A 25,000 year tropical climate history from Bolivian ice cores. Science 282:1858-1864

Valero-Garcés B, Delgado-Huertas A, Navas A, et al. (2003) Patterns of regional hydrological variability in central-southern Altiplano $\left(18^{\circ}-26^{\circ}\right)$ lakes during the last 500 years. Palaeogeogr, Palaeoclimatol, Palaeoecol 194:319-338

Valero-Garcés B, Grosjean M, Kelts K, et al. (1999) Holocene lacustrine deposition in the Atacama Altiplano: facies models, climate and tectonic forcing. Palaeogeogr Palaeoclimatol Palaeoecol 151:101-125

Valero-Garcés B, Grosjean M, Messerli B, et al. (2000) Late Quaternary Lacustrine Deposition in the Chilean Altiplano $\left(18-28^{\circ} \mathrm{S}\right)$. In: Gierlowski-Kordesch EH, Kelts K (eds) Lake basins trough space and time. AAPG Studies in Geol 46:625-639

Valero-Garcés B, Grosjean M, Schwalb A, et al. (1996) Limnogeology of Laguna Miscanti: evidence of mid to late Holocene moisture changes in the Atacama Altiplano (Northern Chile). J Paleolimnol 16:1-21

Vink A, Baumann K, Böckel B, et al. (2003) Coccolithophorid and 
dinoflagellate synecology in the South and Equatorial Atlantic: improving the paleoecological significance of phytoplanktonic microfossils. In: Wefer G, Mulitza S, Ratmeyer V (eds) The South Atlantic in the Late Quaternary: reconstruction of material budgets and current systems. Springer-Verlag, Berlin, pp 101-120

Vlag P, Kruiver P, Dekkers M (2004) Evaluating climate change by multivariate statistical techniques on magnetic and chemical properties of marine sediments (Azores region). Palaeogeogr Palaeoclimatol Palaeoecol 212:23-44

Wörner G, Hammerschmidt K, Henjes-Huns F, et al. (2000) Geochronology $\left({ }^{40} \mathrm{Ar} /{ }^{39} \mathrm{Ar}, \mathrm{K}-\mathrm{Ar}\right.$ and He-exposure ages) of Cenozoic magmatic rocks from Northern Chile $\left(18^{\circ}-22^{\circ} \mathrm{S}\right)$ : implications for magmatism and tectonic evolution of the central Andes. Rev Geol Chile 27:205-240

Wörner G, Harmon R, Davidson J, et al. (1988) The Nevados de Payachata volcanic region $\left(18^{\circ} \mathrm{S} / 69^{\circ} \mathrm{W}\right.$, N. Chile). I. Geological, geochemical, and isotopic observations. Bull Volcanol 50:287-303 


\section{Figure Captions}

Figure 1: (A) Location of Lago Chungará in South America. (B) Bathymetric map of Lago Chungará and location of the cores.

Figure 2: Mineralogy (expressed as percentages on total dry weight), magnetic susceptibility (expressed as standard units), Total Biogenic Silica (TBS), Total Carbon (TC), Total Organic Carbon (TOC) (expressed as percentages) and graycolour curves of the Lago Chungará sediments.

Figure 3: Analysed light and heavy elements (expressed as counts per second) in the sediments of Lago Chungará. The zones correspond to those established in Moreno et al. (2007).

Figure 4: Redundacy Analysis (RDA) carried out on the dataset. The mineralogical species dataset was used as constraining matrix (arrows) whereas the rest of the dataset were considered as data matrix (crosses). The five red circles mark the five main 'families', suggesting their possible origin (for further details see text).

Figure 5: Stratigraphically-unconstrained cluster dendrogram performed in the database, and identification of the three families of samples (see text for further details).

Figure 6: Plot of the samples (numbers) and the variables (arrows) in the plane defined by the first two eigenvectors of the Principal Component Analysis.

Figure 7: Chronological framework of Lago Chungará constructed using $15{ }^{14} \mathrm{C}$ AMS dates and after applying the Heegaard's method (Heegaard et al, 2005) in calendar years BP (modified from Moreno et al. (2007)). The dotted line represents the chronological model constructed considering a constant reservoir-effect of 3,260 years. The dashed line symbolizes the chronological model considering a reservoireffect of 3,260 years for the upper sedimentary unit and of 0 years for the lower one. The intermediate continuous line represents the average model of the two earlier ones and is applied to Lago Chungará. Horizontal bars are the confidence error of the radiometric dates after applying the method of Heegaard. See text for further details.

Figure 8: Reconstruction of the evolution of the volcanic input in Lago Chungará for the last 12,300 cal years BP (right) and comparison of this reconstruction with the dust particle (> $63 \mu \mathrm{m}$ ) content of the Nevado Sajama ice core record (left) (modified from Thompson et al. (1998)). Asterisks denote the location of the main ash layers in the Lago Chungará sediments (Sáez et al, 2007). See text for further details.

Figure 9: Latitudinal comparison of the reconstructed evolution of the water availability in the Lago Chungará, with the $\Omega{ }^{18} \mathrm{O}$ record of Paco Cocha (modified from Abbott et al. (2003)), the percentage of benthic diatoms of Lake Titicaca (modified from Baker et al. (2001b)) and the natural gamma radiation of the Salar Uyuni (modified from Thompson et al. (1998)) for the last 12,300 cal. years BP. 




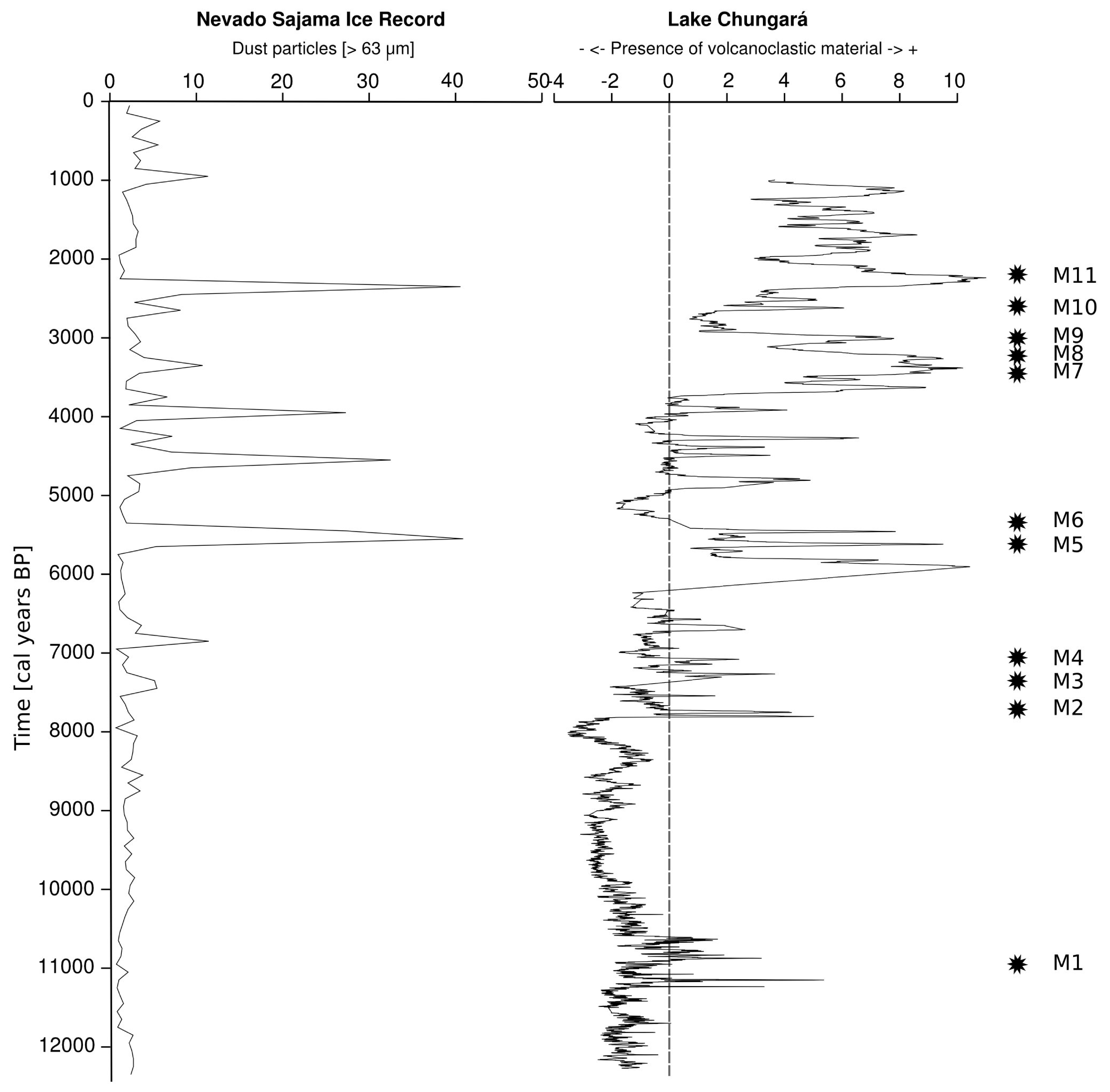


Time (calendar years BP)

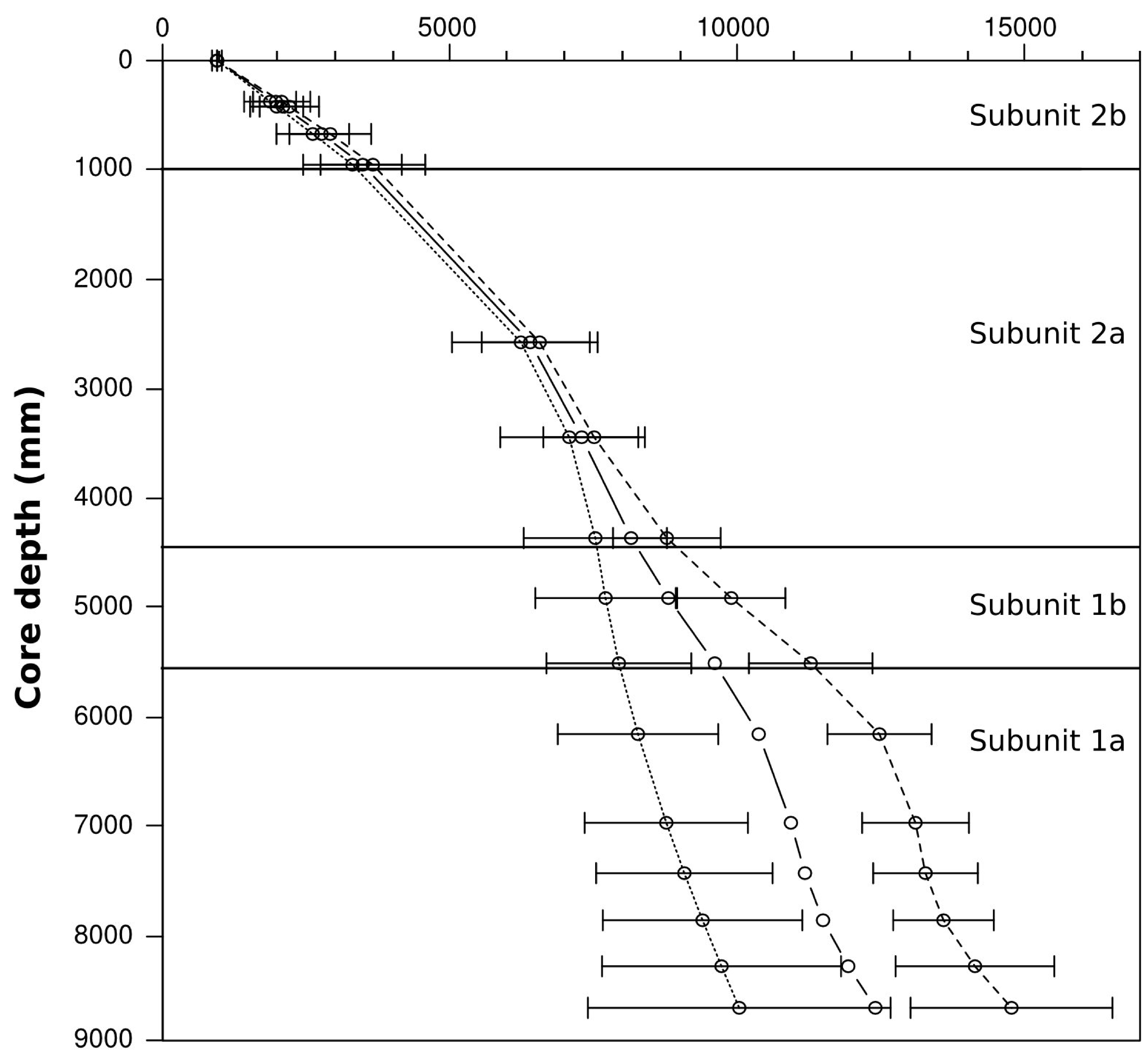









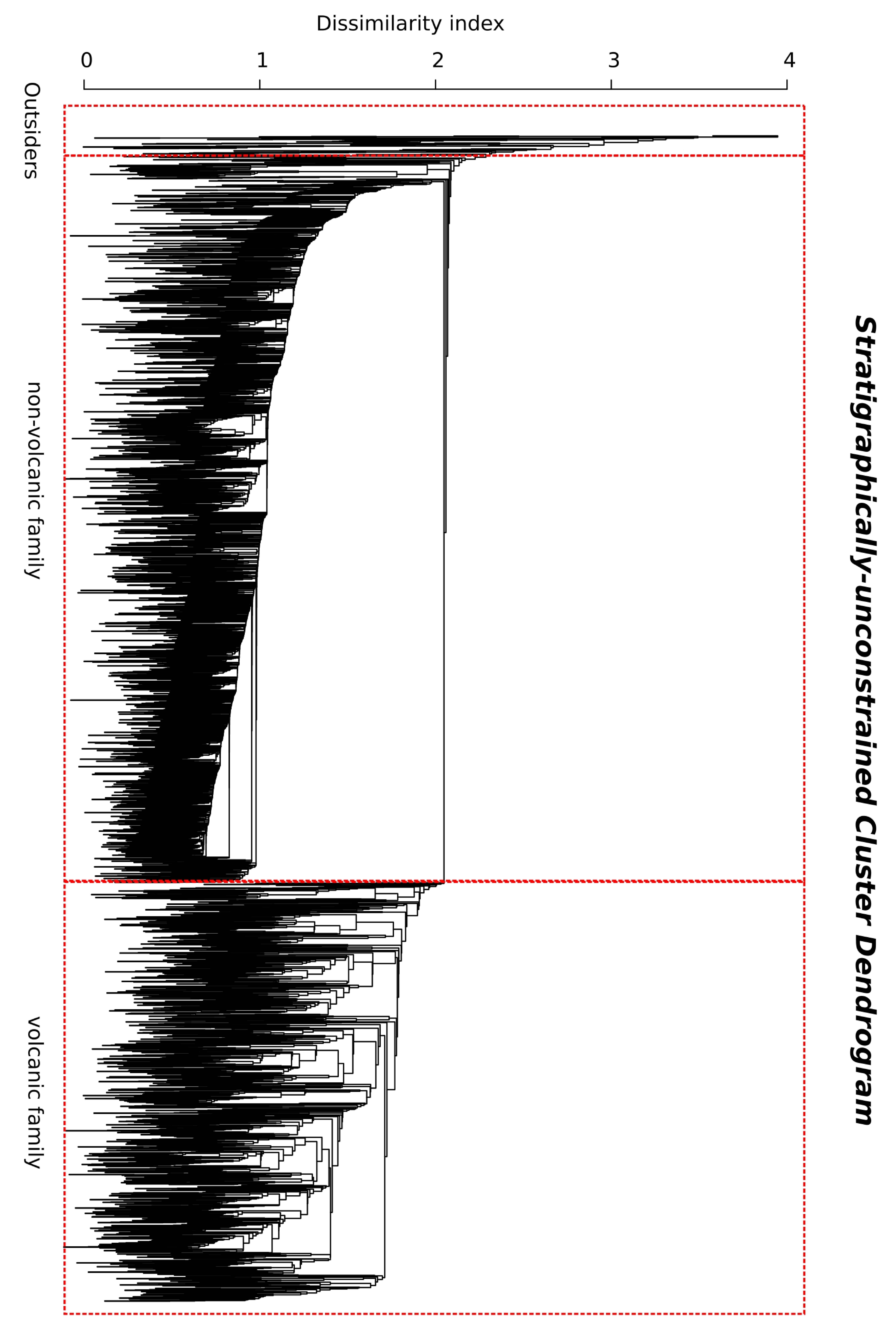




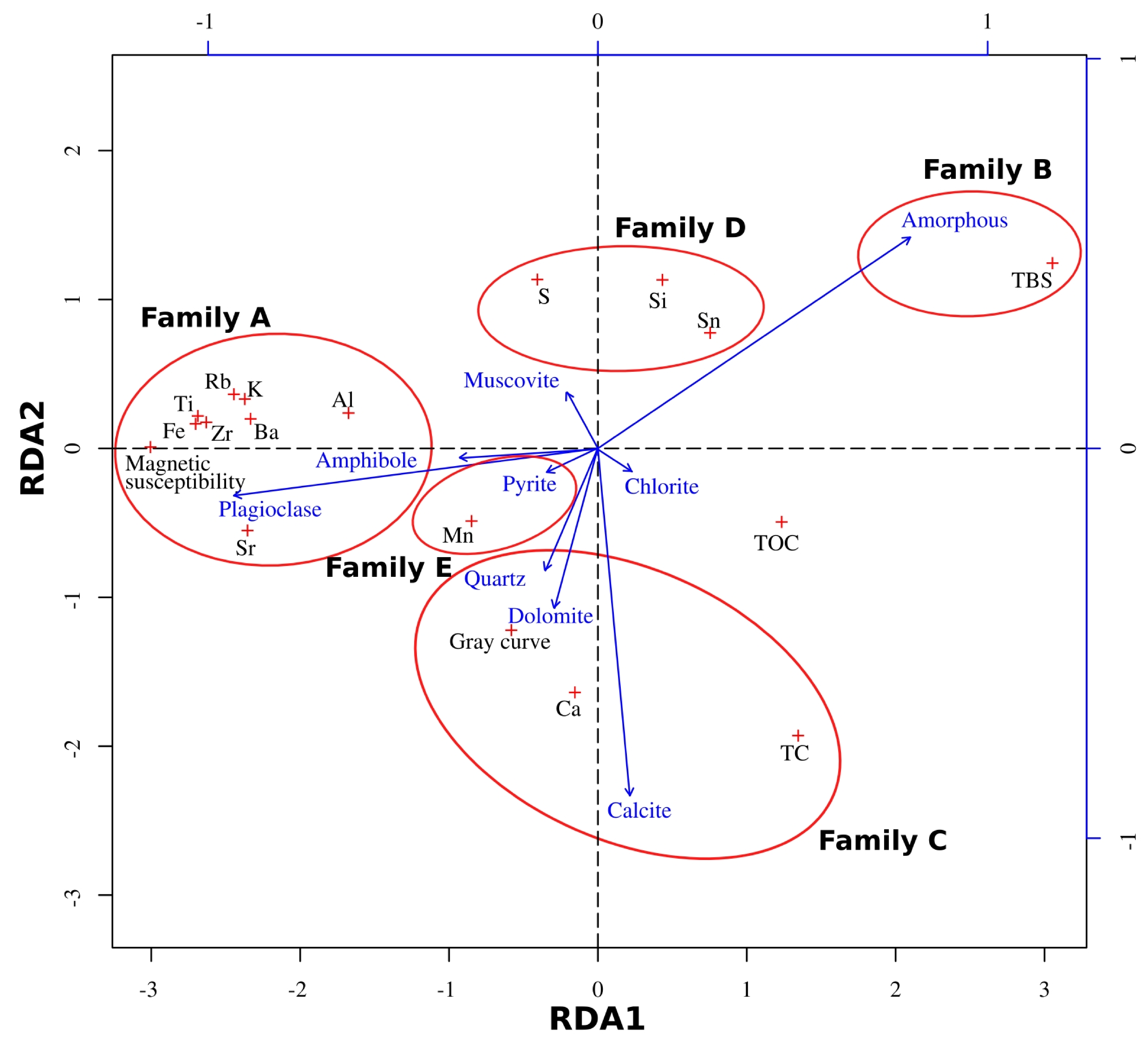




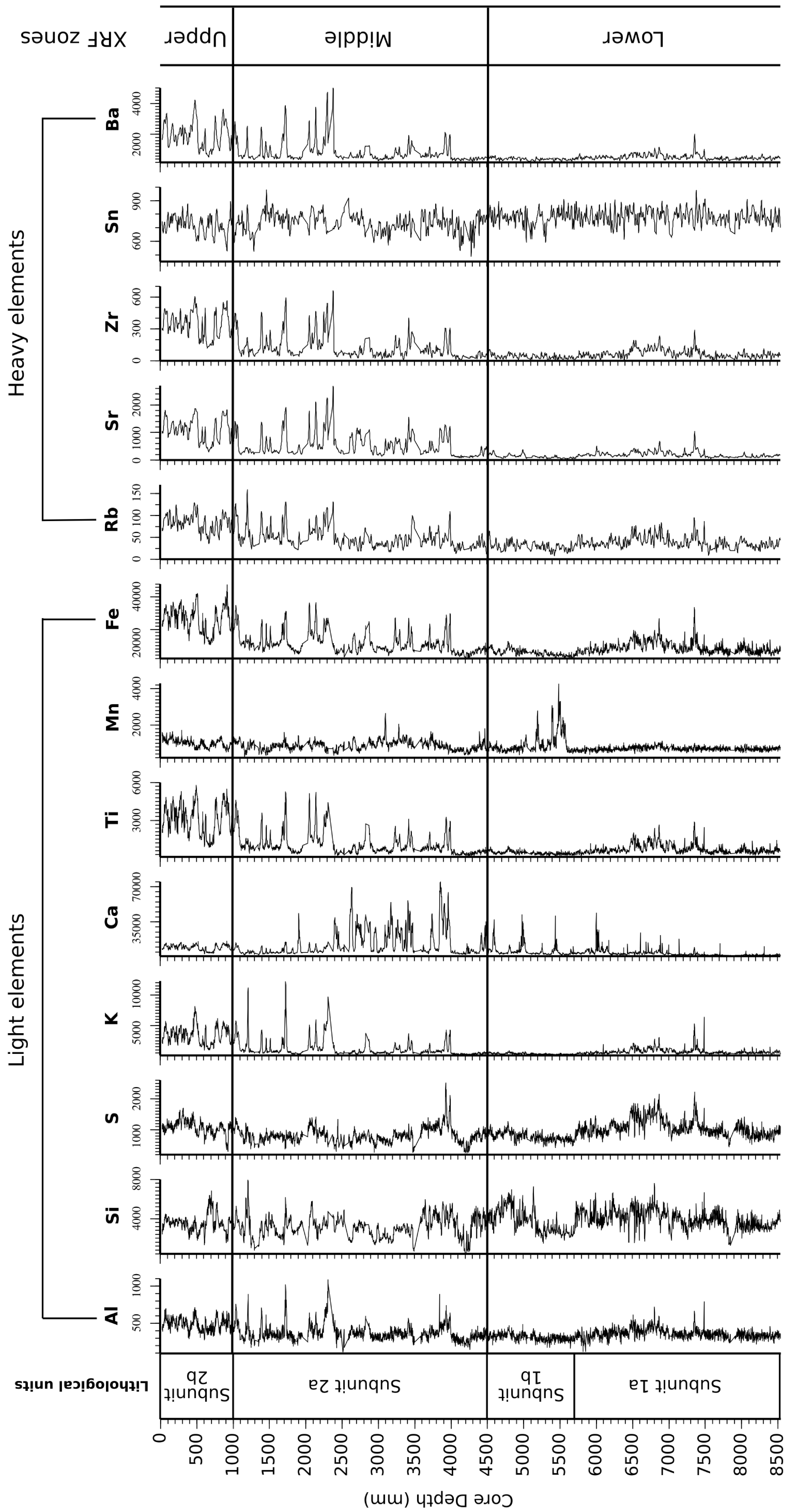




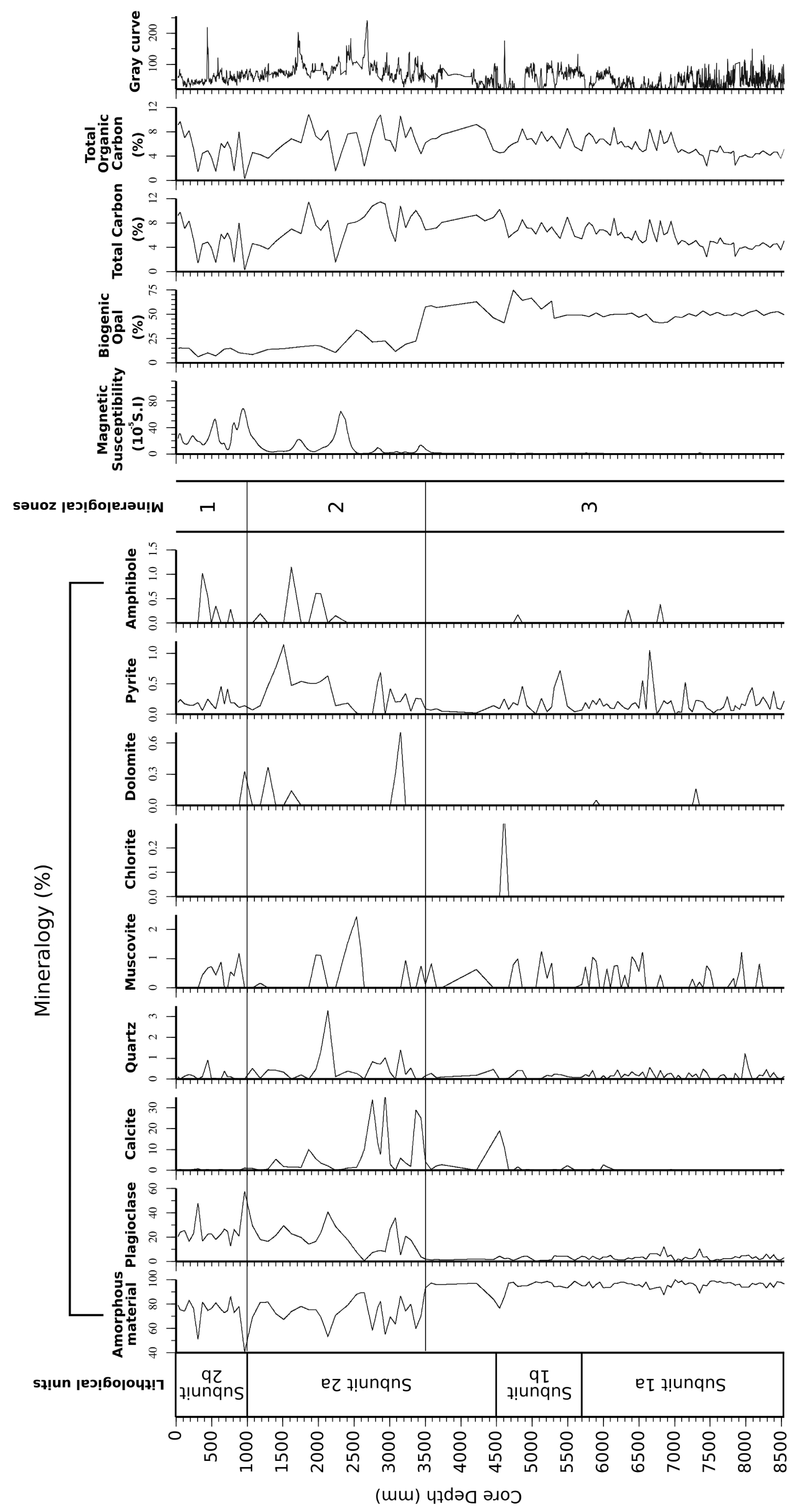




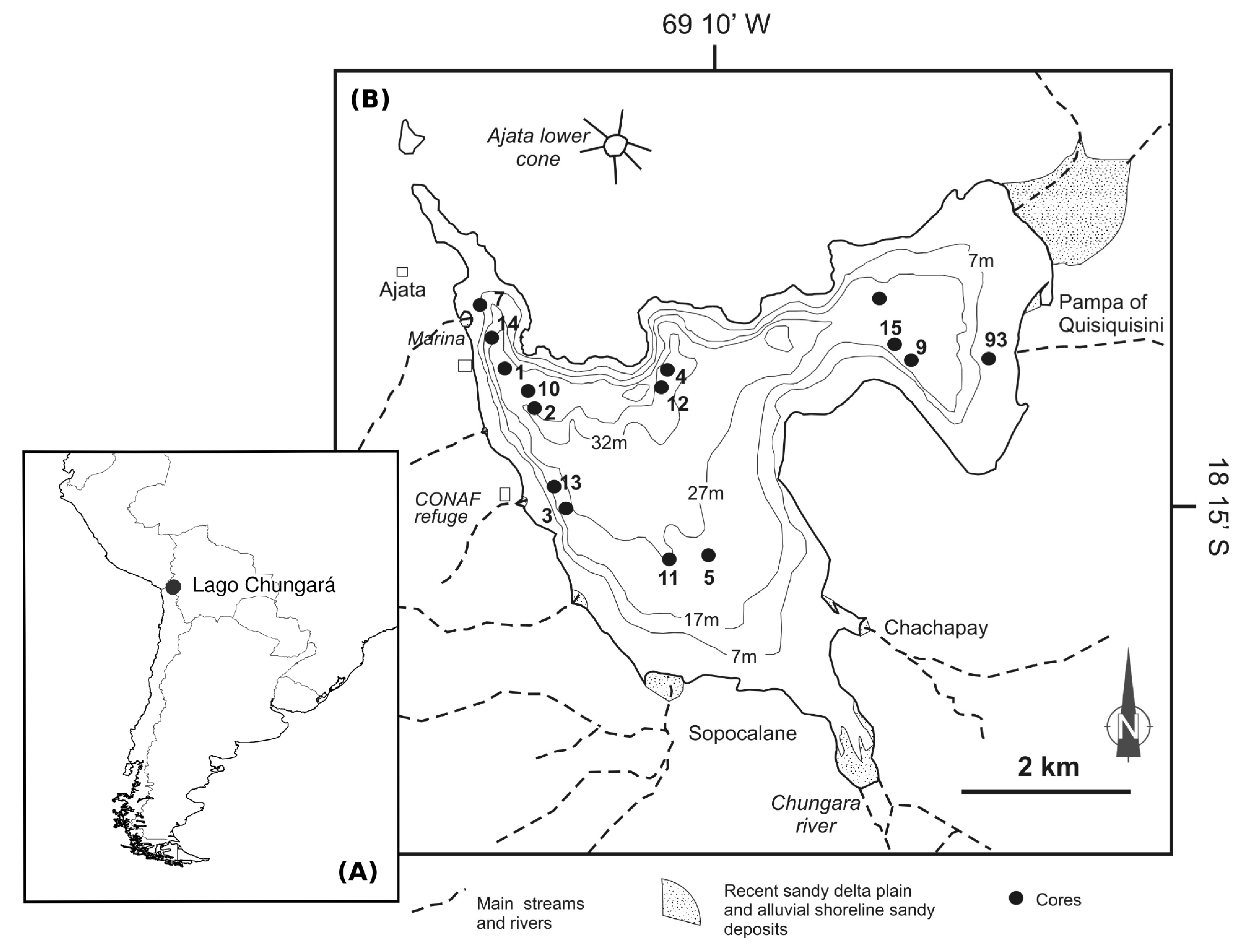

